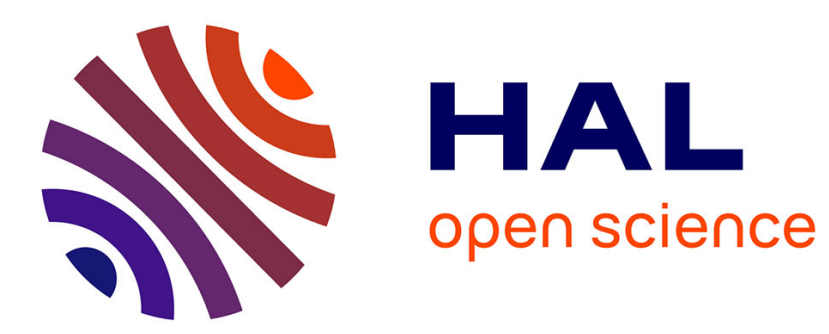

\title{
Degradation of enoxacin antibiotic by the electro-Fenton process: Optimization, biodegradability improvement and degradation mechanism
}

Cyrine Annabi, Florence Fourcade, Isabelle Soutrel, Florence Geneste, Didier

Floner, Nizar Bellakhal, Abdeltif Amrane

\section{To cite this version:}

Cyrine Annabi, Florence Fourcade, Isabelle Soutrel, Florence Geneste, Didier Floner, et al.. Degradation of enoxacin antibiotic by the electro-Fenton process: Optimization, biodegradability improvement and degradation mechanism. Journal of Environmental Management, 2016, 165, pp.96-105. 10.1016/j.jenvman.2015.09.018 . hal-01208401

\section{HAL Id: hal-01208401}

https://hal-univ-rennes1.archives-ouvertes.fr/hal-01208401

Submitted on 5 Nov 2015

HAL is a multi-disciplinary open access archive for the deposit and dissemination of scientific research documents, whether they are published or not. The documents may come from teaching and research institutions in France or abroad, or from public or private research centers.
L'archive ouverte pluridisciplinaire HAL, est destinée au dépôt et à la diffusion de documents scientifiques de niveau recherche, publiés ou non, émanant des établissements d'enseignement et de recherche français ou étrangers, des laboratoires publics ou privés. 


\title{
Degradation of enoxacin antibiotic by the electro-Fenton process: Optimization, biodegradability improvement and degradation mechanism
}

\author{
Cyrine Annabi $^{\mathrm{a}, \mathrm{b}, \mathrm{c}, \mathrm{,}}$, Florence Fourcade ${ }^{\mathrm{a}, \mathrm{e}}$, Isabelle Soutrel ${ }^{\mathrm{a}, \mathrm{e}}$, Florence Geneste ${ }^{\mathrm{d}, \mathrm{e}}$, Didier \\ Floner $^{\mathrm{d}, \mathrm{e}}$, Nizar Bellakhal ${ }^{\mathrm{b}, \mathrm{c}}$, Abdeltif Amrane ${ }^{\mathrm{a}, \mathrm{e}}$ \\ ${ }^{a}$ Institut des Sciences Chimiques de Rennes, Ecole Nationale Supérieure de Chimie de \\ Rennes, Université de Rennes 1, UMR-CNRS 6226, 11 Allée de Beaulieu, CS 50837, \\ 35708 Rennes Cedex 7, France \\ ${ }^{\mathrm{b}}$ Centre d'Electrochimie de Nanomatériaux et Leurs Applications et de Didactique \\ (CENAD), France \\ ${ }^{c}$ Institut National des Sciences Appliquées et de Technologie, B.P. No. 676, 1080 Tunis \\ Cedex, Tunisia \\ d Institut des Sciences Chimiques de Rennes, Université de Rennes 1, UMR-CNRS 6226, \\ Campus de Beaulieu, 35042 Rennes Cedex, France \\ ${ }^{\mathrm{e}}$ Université Européenne de Bretagne, 5 Boulevard Laënnec, 35000, France
}

\section{Highlights}

- The efficiency of the electro-Fenton process on the removal of enoxacin was investigated. A total degradation of the target molecule was observed. $\bullet$ The biodegradability increased from 0 to 0.5 for the $\mathrm{BOD}_{5}$ on $\mathrm{COD}$ ratio. $\cdot$ By-products were identified by UPLC-MS/MS and a degradation pathway was proposed.

\begin{abstract}
This study aims to investigate the effectiveness of the electro-Fenton process on the removal of a second generation of fluoroquinolone, enoxacin. The electrochemical reactor involved a carbon-felt cathode and a platinum anode. The influence of some experimental parameters, namely the initial enoxacin concentration, the applied current intensity and the Fe(II) amount, was examined. The degradation of the target molecule was accompanied by an increase of the biodegradability, assessed from the $\mathrm{BOD}_{5}$ on $\mathrm{COD}$ ratio, which increased from 0 before treatment until 0.5 after $180 \mathrm{~min}$ of electrolysis at $50 \mathrm{mg} \mathrm{L}^{-1}$ initial enoxacin concentration, $0.2 \mathrm{mmol} \mathrm{L}^{-1} \mathrm{Fe}(\mathrm{II})$ concentration and $300 \mathrm{~mA}$ applied current intensity. TOC and COD timecourses were also evaluated during electrolysis and reached maximum residual yields of $54 \%$ and $43 \%$ after $120 \mathrm{~min}$ of treatment, respectively. Moreover, a simultaneous generation of inorganic ions (fluorides, ammonium and nitrates) were observed and 3 short chain carboxylic acids (formic, acetic and oxalic acids) were identified and monitored during $180 \mathrm{~min}$ of electrolysis. By-products were identified according to UPLC-MS/MS results and a degradation pathway was proposed.
\end{abstract}




\section{Keywords}

- Electro-Fenton process;

- Enoxacin removal;

- Hydroxyl radicals;

- Biodegradability improvement;

- By-products

\section{Introduction}

In recent years, treating environmental hazards due to the significant detection of pharmaceutical compounds in wastewater became an area of interest for the scientific community worldwide (Ellis, 2006, Sui et al., 2011 and Yoon et al., 2010). Excretion after administration and wastes in the production sites are the main causes of the presence of pharmaceutical compounds in the aquatic environment (Bound and Voulvoulis, 2005). This type of compounds has been recently classified as a priority risk pollutants (Hernando et al., 2006 and Watkinson et al., 2009). Most of them are antibiotics. Their presence in wastewater is responsible for the development of antimicrobial resistance among microorganisms (Levy, 1998). Owing to their recalcitrance, the commonly employed treatment processes (biological processes) appear not effective enough for a complete removal of such species. The contamination by these micropollutants is observed not only in the received water but reached also surface waters. Their toxic and adverse effects were proven in previous studies (Daughton and Ternes, 1999 and Giger et al., 2003).

Fluoroquinolones (FQs) are the third largest group of antibiotics with 17\% of the global market share (Van Doorslaer et al., 2014). They are frequently detected with relatively high concentrations in hospital wastewaters $\left(3 \mathrm{ng} \mathrm{L}^{-1}-240 \mu \mathrm{g} \mathrm{L}^{-1}\right)$, urban wastewaters $\left(2 \mathrm{ng} \mathrm{L}^{-1}\right.$ $\left.14 \mu \mathrm{g} \mathrm{L}^{-1}\right)$ and in bulk drug producer wastewaters $\left(6 \mathrm{ng} \mathrm{L}^{-1}-31 \mathrm{mg} \mathrm{L}^{-1}\right.$ (Golet et al., 2002, Lin et al., 2008 and Van Doorslaer et al., 2014). FQs are also observed in livestock and aquaculture wastewaters (Van Doorslaer et al., 2014). Their broad antimicrobial spectrum may lead to the proliferation of bacterial drug resistance (Watkinson et al., 2007). FQs are characterized by their chemical stability and their high resistance to hydrolysis and to high temperatures, due to their quinolone ring. Conventional water treatment plants show a high variation in FQ removal efficiency (between 47 and 77\% on average) (Van Doorslaer et al., 2014). However, it is suggested by several authors that the predominant removal mechanism for FQ compounds is sorption to activated sludge rather than biodegradation (Hendricks and Pool, 2012, Lindberg et al., 2006 and Van Doorslaer et al., 2014). A previous study reported that more than $80 \%$ of the total amount of ciprofloxacin and norfloxacin (FQ molecules) treated in a sewage treatment plant in Sweden was ultimately found in the digested sludge (Lindberg et al., 2006). This behavior is due to the high affinity of FQs for sludge, soils and sediments, through electrostatic and hydrophobic interactions (Lindberg et al., 2006).

Therefore, an effective strategy must be found to degrade these compounds from aquatic matrices and to enhance their biodegradability as a pretreatment before their discharge into sewage treatment plants. 
Advanced Oxidation Processes (AOP) have received great interest in recent years as an alternative method to treat organic and recalcitrant molecules (Nasuhoglu et al., 2012). Some recent review papers reported the relevance of AOP on the degradation and the mineralization of residual molecules (Feng et al., 2013, Klavarioti et al., 2009, Pera-Titus et al., 2004 and Sirés et al., 2014). These oxidative treatment processes can be classified into four categories: chemical oxidation processes in homogeneous phase $\left(\mathrm{H}_{2} \mathrm{O}_{2} / \mathrm{Fe}(\mathrm{II})\right.$ and $\left.\mathrm{H}_{2} \mathrm{O}_{2} / \mathrm{O}_{3}\right)$; photocatalytic processes in homogeneous phase and/or heterogeneous phase $\left(\mathrm{H}_{2} \mathrm{O}_{2} / \mathrm{UV}\right.$, $\mathrm{O}_{3} / \mathrm{UV}, \mathrm{Fe}(\mathrm{II}) / \mathrm{H}_{2} \mathrm{O}_{2} / \mathrm{UV}$ and $\left.\mathrm{TiO}_{2} / \mathrm{UV}\right)$; oxidation by sonochemical processes and electrochemical oxidation processes. AOP are characterized by the in-situ production of hydroxyl radicals $(\mathrm{OH})$ that are very strong oxidants $\left(\mathrm{E}^{\circ}\left(\mathrm{OH} / \mathrm{H}_{2} \mathrm{O}\right)=2.81 \mathrm{~V} / \mathrm{SHE}\right.$ at $\left.25^{\circ} \mathrm{C}\right)$ able to oxidize complex organic molecules such as pesticides (Guivarch et al., 2003), industrial dyes (Hammami et al., 2008) and pharmaceuticals (An et al., 2010, Guinea et al., 2010, Ikehata et al., 2006, Mansour et al., 2012 and Rodrigues-Silva et al., 2013).

The electro-Fenton Process (EF) is one of the most efficient electrochemical AOP, which consists in the continuous production of hydroxyl radicals using electrogenerated Fenton reagent $\left(\mathrm{H}_{2} \mathrm{O}_{2} / \mathrm{Fe}(\mathrm{II})\right)$ according to the reactions below (El-Desoky et al., 2010 and Xie and $\mathrm{Li}, 2006)$ :

$\mathrm{O}_{2}+2 \mathrm{H}^{+}+2 \mathrm{e}^{-} \rightarrow \mathrm{H}_{2} \mathrm{O}_{2} \mathrm{O} 2+2 \mathrm{H}++2 \mathrm{e}^{-} \rightarrow \mathrm{H} 2 \mathrm{O} 2$

$\mathrm{H}_{2} \mathrm{O}_{2}+\mathrm{Fe}^{2+} \rightarrow \mathrm{Fe}^{3+}+\mathrm{OH}^{-}+\mathrm{OHH} 2 \mathrm{O} 2+\mathrm{Fe} 2+\rightarrow \mathrm{Fe} 3++\mathrm{OH}-+\mathrm{OH}$

$\mathrm{Fe}^{3+}+1 \mathrm{e}^{-} \rightarrow \mathrm{Fe}^{2+} \mathrm{Fe} 3++1 \mathrm{e}^{-} \rightarrow \mathrm{Fe} 2+$

EF achieves high reaction yields and may be considered as an environmentally clean process (El-Desoky et al., 2010).

Studies dealing with FQ degradation using AOP are numerous. Flumequine degradation was investigated by EF and by photo-electro-Fenton (PEF) in a non divided electrochemical cell using a Carbon-PTFE-air diffusion cathode and a Boron Doped Diamond (BDD) anode. Results showed an almost total mineralization in $360 \mathrm{~min}$ at $300 \mathrm{~mA}$ current intensity for both EF and PEF (Garcia-Segura et al., 2012). Ciprofloxacin was completely degraded by EF within 8 min and reached $94 \%$ of mineralization after 360 min of treatment using a carbon felt cathode and Platinum (Pt) anode (Yahya et al., 2014). Its degradation was also studied by sonochemistry (Xiao et al., 2014). Anodic oxidation and Solar-photo-electro-Fenton have been tested for Enrofloxacin elimination in an undivided filter press coupled to a photoreactor and using a batch recirculation flow plant. Investigations reported $28 \%$ and $86 \%$ of mineralization yields respectively after 300 min of treatment with a BDD anode and a Carbon PTFE gas diffusion cathode (Guinea et al., 2010). Nasuhoglu et al. demonstrated the efficiency of ozonation and $\mathrm{TiO}_{2}$ photocatalysis to degrade Levofloxacin leading to maximal oxidation yields of 59\% and $70 \%$ respectively after 300 min of treatment (Nasuhoglu et al., 2012). The efficiency of photocatalysis was also verified for moxifloxacin (Van Doorslaer et al., 2015). 
However, there is a lack of studies dealing with the effectiveness of coupling AOP with a biological treatment for FQs. The effectiveness of this type of coupling has been proven with other classes of antibiotics such as sulfonamides (sulfamethazine) (Mansour et al., 2012), macrolides (tylosin) (Yahiat et al., 2011) and tetracycline (Ferrag-Siagh et al., 2013).

Therefore, the focus of this study is to evaluate the applicability of EF for the pretreatment of enoxacin (ENO), an oral broad-spectrum FQ antibacterial agent, used in the treatment of respiratory and urinary tract infections (Patel and Spencer, 1996) and to assess the possibility of coupling EF and a biological process for enoxacin mineralization. In this sense, the biodegradability of the degraded solution was examined. By-products and inorganic species were analyzed as well.

\section{Materials and methods}

\subsection{Chemicals}

Enoxacin (1-ethyl-6-fluoro-4-oxo-7-(piperazin-1-yl)-1,4-dihydro-1,8-naphthyridine-3carboxylic acid) was generously provided by the LNCM (Laboratoire National de Contrôle des Médicaments - Tunis, Tunisia) (structure displayed in Fig. 1).<smiles>CCn1cc(C(=O)O)c(=O)c2cc(F)c(N3CCNCC3)nc21</smiles>

Fig. 1.

Molecular structure of enoxacin.

$\mathrm{FeSO}_{4} \cdot 7 \mathrm{H}_{2} \mathrm{O}$ (purity 99\%) and $\mathrm{Na}_{2} \mathrm{SO}_{4}$ (purity 99\%) were used as catalyst and a supporting electrolyte respectively and were purchased from Acros Organics (Thermo Fisher Scientific, Illkirch, France). Acetonitrile (purity 99.9\%) (HPLC grade) was obtained from SigmaAldrich (Saint Quentin Fallavier, France). The initial pH of the solutions was adjusted to 3, the optimal $\mathrm{pH}$ value for the electro-Fenton process (Diagne et al., 2007), by adding analytical grade sulfuric acid $\mathrm{H}_{2} \mathrm{SO}_{4}$ purchased from Acros Organics. All solutions were prepared with ultrapure water and all the other chemicals used for analysis were supplied from Acros Organics and Sigma Aldrich.

\subsection{Electrochemical apparatus and procedures}

Experiments were performed at room temperature $\left(18{ }^{\circ} \mathrm{C}\right)$ with an undivided cylindrical glass cell containing $250 \mathrm{~mL}$ of solution. The cell was equipped with two electrodes, a tridimensional carbon felt piece (Carbone Lorraine RVG 4000 Mersen, Paris La Défense, France) as cathode $(90 \mathrm{~mm} \times 50 \mathrm{~mm} \times 12 \mathrm{~mm})$ and a cylindrical platinum $(\mathrm{Pt})$ electrode $\left(34.6 \mathrm{~cm}^{2}\right)$ as anode, located in the center of the electrochemical reactor to have a good 
potential distribution. Compressed air was bubbled for $10 \mathrm{~min}$ through the cell to saturate the solution prior to electrolysis. The treated solutions contained a catalytic quantity of $\mathrm{FeSO}_{4} \cdot 7 \mathrm{H}_{2} \mathrm{O}$ and their $\mathrm{pH}$ was adjusted to 3 . Electrolyzes were carried out under current controlled conditions. The current was kept at the desired level with a DC power supply (Metrix, model AX 322-Chauvin Arnoux Group, Paris, France) operating in galvanostatic mode to control the current intensity. The ionic strength was maintained constant with the addition of $50 \mathrm{mmol} \mathrm{L}^{-1} \mathrm{Na}_{2} \mathrm{SO}_{4}$.

\subsection{Analytical procedure}

\subsubsection{Electrochemical analysis}

Electrochemical analysis of ENO was performed using a conventional three-electrodes cell with a vitreous carbon disk electrode $\left(3.14 \mathrm{~mm}^{2}\right)$ as the working electrode and a Pt wire as the counter electrode. All the electrode potentials were measured with respect to an $\mathrm{Ag} / \mathrm{AgCl}$ electrode located near to the working electrode. Experiments were performed at ambient temperature under nitrogen atmosphere to avoid dissolved oxygen. Voltammograms were obtained with a scan rate of $20 \mathrm{mV} \mathrm{s}^{-1}$ using a BioLogic SP-150 potentiostat recorded to ECLab V10.36 software.

\subsubsection{High performance liquid chromatography (HPLC)}

The evolution of ENO concentrations was monitored by HPLC using a Waters 996 system equipped with Waters 996 PDA (Photodiode Array Detector) and Waters 600LCD Pump. The separation was achieved on a Waters C-18, $(5 \mu \mathrm{m} ; 4.6 \times 250 \mathrm{~mm})$ reversed-phase. Analyses were carried out isocratically using a mixture of acetonitrile/MilliQ water $(10 / 90, \mathrm{v} / \mathrm{v})$ with $0.1 \%$ formic acid as eluent, at a flow rate of $1 \mathrm{~mL} \mathrm{~min}^{-1}$. Detection of ENO was performed at $270 \mathrm{~nm}$ and the retention time was approximately $12 \mathrm{~min}$.

\subsubsection{Total organic carbon (TOC) and total nitrogen (TN) measurements}

TOC and TN were measured by means of a TOC- $\mathrm{V}_{\mathrm{CPH} / \mathrm{CPG}}$ Total Organic Analyzer Schimadzu. Organic Carbon compounds were combusted and converted to $\mathrm{CO}_{2}$ which was detected by a non-dispersive Infra-Red Detector (NDIR). Dissolved Nitrogen compounds were combusted and converted to NO which was then mixed with Ozone chemiluminescence for detection by a photomultiplier.

\subsubsection{Chemical oxygen demand (COD) measurements}

COD was measured by means of a Test Nanocolor ${ }^{\circledR}$ CSB 40 and 160 from Macherey-Nagel (Düren, Germany) (Mansour et al., 2012).

\subsubsection{Biochemical oxygen demand $\left(\mathrm{BOD}_{5}\right)$ measurements}

$\mathrm{BOD}_{5}$ measurements were carried out in Oxitop IS6 (from WTW) in order to evaluate the biodegradability for ENO molecule and its by-products. Inoculation of samples, blank solution and control solution was performed according to the following procedure: $100 \mathrm{~g}$ of activated sludge (collected from a local wastewater treatment plant) was mixed in distilled water; after agitation the solution was left stand for $10 \mathrm{~min}$; and $20 \mathrm{~mL}$ of supernatant was then harvested and mixed to distilled water to obtain a total volume of $2 \mathrm{~L}$. The following 
mineral basis was used for all experiments $\left(\mathrm{g} \mathrm{L}^{-1}\right)$ : $\mathrm{MgSO}_{4} \cdot 7 \mathrm{H}_{2} \mathrm{O}, 22.5 ; \mathrm{CaCl}_{2}, 27.5 ; \mathrm{FeCl}_{3}$, $0.15 ; \mathrm{NH}_{4} \mathrm{Cl}, 2.0 ; \mathrm{Na}_{2} \mathrm{HPO}_{4}, 6.80 ; \mathrm{KH}_{2} \mathrm{PO}_{4}, 2.80$. The $\mathrm{BOD}_{5}$ value was initially estimated based on the COD value experimentally measured or calculated, $\mathrm{BOD}_{5}=\mathrm{COD} / 1.46$.

Neutral $\mathrm{pH}(7.0 \pm 0.2)$ was adjusted for all the samples by adding $\mathrm{NaOH}$ (Chebli et al., 2010).

\subsubsection{Inorganic ions quantification}

The monitoring of ammonium species $\left(\mathrm{NH}_{4}{ }^{+}\right)$was realized via the spectrophotometric method of Nessler at $420 \mathrm{~nm}$ (Rodier et al., 1996). Fluorides were quantified according to the standard additions method, using a specific fluoride electrode (Yam et al., 1995). Nitrate and Nitrite ions monitoring was carried out by a spectrophotometric method at $415 \mathrm{~nm}$ and $543 \mathrm{~nm}$, respectively (Rodier et al., 1996).

\subsubsection{Liquid chromatography-mass spectrometry (UPLC-MS/MS)}

The devices used are detailed in a previous work (Assassi et al., 2011). The analytes were separated by a Waters Acquity UPLC system (Waters Corporation, Milford, MA, USA) consisting of an Acquity UPLC binary solvent manager, an Acquity UPLC sample manager and an Acquity UPLC column heater equipped with a Waters Acquity UPLC BEH Shield RP18 column ( $2.1 \mathrm{~mm} \times 100 \mathrm{~mm}, 1.7 \mu \mathrm{m}$ particle size) (Milford, MA, USA) maintained at $45^{\circ} \mathrm{C}$. Analyses were performed using $0.1 \%$ formic acid in acetonitrile as eluent $\mathrm{A}$ and $0.1 \%$ formic acid in a mixture of MilliQ Water/Acetonitrile $(90 / 10, \mathrm{v} / \mathrm{v})$ as eluent $\mathrm{B}$, delivered at a

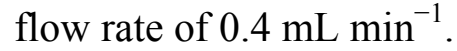

The elution gradient started with $0 \%$ of eluent A and increased linearly to $100 \%$ of A within 5 min.

The separated compounds were detected with a Waters Micromass Quattro Premier (Waters Corporation, Manchester, UK) triple quadruple mass spectrometer. It was operating with an electrospray source in positive ionization mode with a cone potential of $30 \mathrm{~V}$. The ionization source conditions were: capillary voltage of $3.0 \mathrm{kV}$ and source temperature of $350{ }^{\circ} \mathrm{C}$. The cone and desolvation gas flows were $50 \mathrm{~L} \mathrm{~h}^{-1}$ and $750 \mathrm{~L} \mathrm{~h}^{-1}$, respectively. They were obtained from an in-house nitrogen source, the Peak Scientific NM30LA (Peak Scientific, Inchinann, United Kingdom). High-purity argon (99.99\%, Air Liquid, Paris, France) was used as collision gas and was regulated at $0.1 \mathrm{~mL} \mathrm{~min}^{-1}$. Analyses were performed in full scan and daughter scan modes, with a collision energy of $25 \mathrm{eV}$. Spectra were acquired between 80 and $500 \mathrm{mz}^{-1}$ and the data were treated with Micromass Mass-Lynx 4.1 software.

\subsubsection{Ionic chromatography (CI)}

Generated carboxylic acids were identified by DIONEX DX120 ion chromatography equipped with a conductivity detector, using an anion exchange column AS19 $(4 \times 250 \mathrm{~mm})$ as the stationary phase, and a solution of $\mathrm{KOH}$ in water as the mobile phase. The analyses were carried out with a gradient elution mode. It started with $10 \mathrm{mmol} \mathrm{L}^{-1}$ of $\mathrm{KOH}$ during $10 \mathrm{~min}$ then increased linearly to $45 \mathrm{mmol} \mathrm{L}^{-1}$ from 10 to 25 min and finished with $45 \mathrm{mmol} \mathrm{L}^{-1}$ of $\mathrm{KOH}$ from 25 to $35 \mathrm{~min}$. The flow rate was set at $1 \mathrm{~mL} \mathrm{m^{-1 }}$ (Yahiat et al., 2011). 


\section{Results and discussion}

\subsection{Electrochemical behavior of enoxacin}

The electrochemical behavior of enoxacin was studied in order to conclude on the contribution of a direct oxidation and/or reduction of the target molecule at the electrode surface to the EF process. For this purpose, current potential curves were plotted by cyclic voltammetry in $\mathrm{Na}_{2} \mathrm{SO}_{4} 50 \mathrm{mmol} \mathrm{L}^{-1}$ supporting electrolyte at $\mathrm{pH} 3$ with $500 \mathrm{mg} \mathrm{L}^{-1}$ of the target compound. In the presence of enoxacin, oxidation and reduction of water were shifted toward anodic and cathodic potentials, respectively. This potential shift was probably due to the adsorption of the target compound onto the electrode surface. A non reproducible signal in reduction was observed around $-1.3 \mathrm{~V} / \mathrm{Ag} / \mathrm{AgCl}$ (Supplementary material 1) which indicated an irreversible electrochemical reaction and the influence of the adsorption of the antibiotic on the peak current. The irreversible reduction of ENO has already been observed and has been attributed to a two electrons reduction of the ketone group of the molecule (Zhang et al., 1996 and Zhou et al., 1995).

The three amines groups were protonated at $\mathrm{pH} \mathrm{3,} \mathrm{thus} \mathrm{no} \mathrm{signal} \mathrm{on} \mathrm{their} \mathrm{oxidation} \mathrm{was}$ observed on the voltammograms.

During the EF process, even if the ketone group was reduced by a direct two electrons transfer at the electrode interface, the formation of alcohol should not significantly enhance the biodegradability of the molecule.

\subsection{Effect of the operating parameters on enoxacin degradation by EF}

The decrease of the ENO concentration during the EF was monitored and different operating conditions were examined, including the initial concentration of ENO, the initial Fe(II) concentration and the applied current intensity.

\subsubsection{Effect of the initial enoxacin concentration}

The electrolysis was carried out at $200 \mathrm{~mA}$, with $0.2 \mathrm{mmol} \mathrm{L}^{-1} \mathrm{Fe}(\mathrm{II})$ and with initial amounts of ENO in the range of 50-200 $\mathrm{mg} \mathrm{L}^{-1}$ (Fig. 2). 


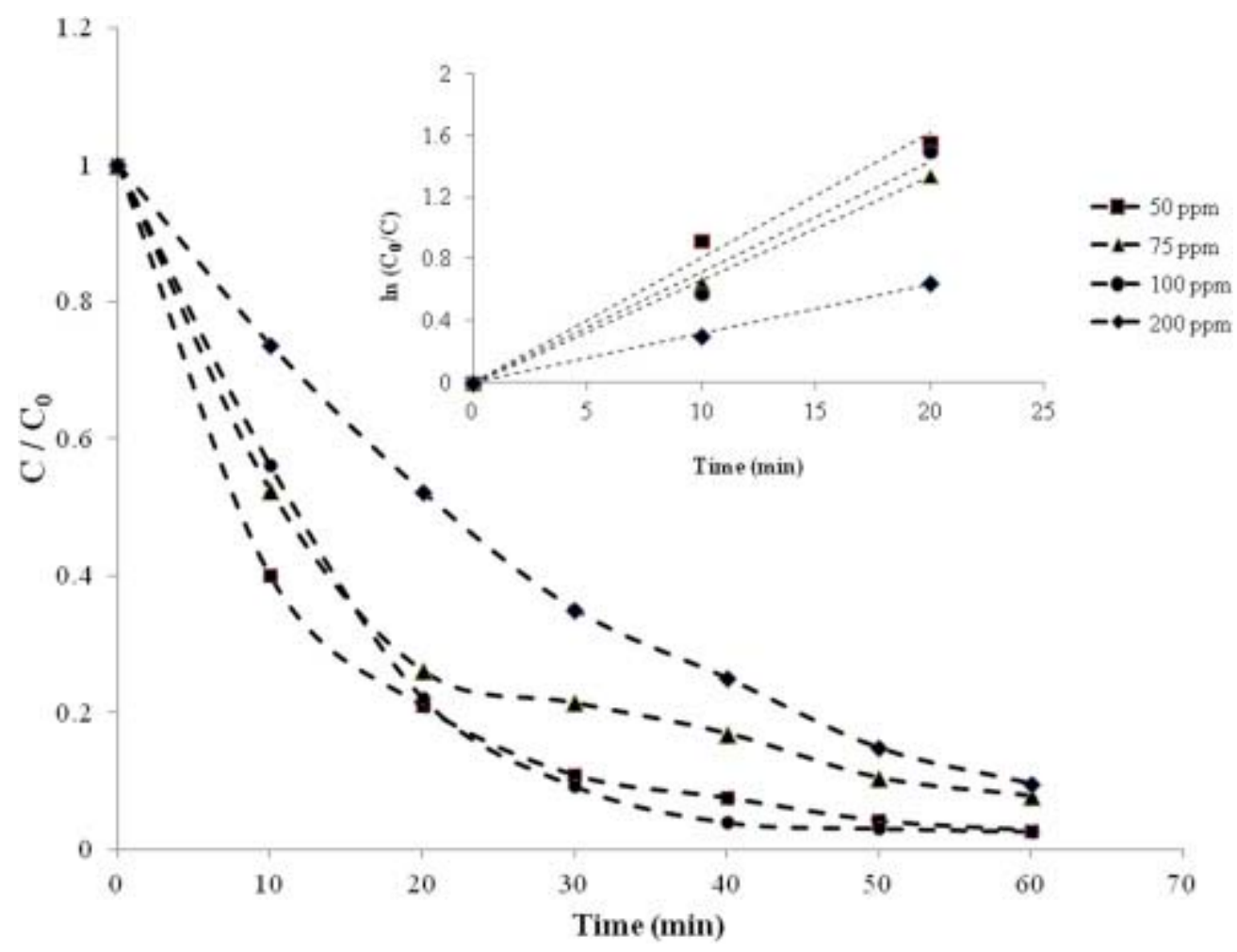

Fig. 2.

Effect of the initial ENO concentration on its degradation and kinetic analysis for the pseudo first-order reaction of ENO. Experimental conditions: $[\mathrm{Fe}(\mathrm{II})]=0.2 \mathrm{mmol} \mathrm{L}^{-1}$, $\mathrm{I}=200 \mathrm{~mA}, \mathrm{pH}=3,\left[\mathrm{Na}_{2} \mathrm{SO}_{4}\right]=50 \mathrm{mmol} \mathrm{L}^{-1}, \mathrm{~V}=250 \mathrm{~mL}$.

The results show a clear impact of the initial ENO amount on the degradation efficiency, especially between 100 and $200 \mathrm{mg} \mathrm{L}^{-1}$ (Fig. 2); while almost similar final degradation yields can be observed after $60 \mathrm{~min}$ (Fig. 2). This trend can be explained by an increase of organic molecules in the solution which requires a greater number of hydroxyl radicals to their degradation (Sirés et al., 2007a). Experimental kinetics can be satisfactorily described by a pseudo-first order reaction kinetic (inset of Fig. 2). The apparent kinetic rate constant values $\left(\mathrm{k}_{\mathrm{app}}\right)$ for the oxidation of ENO correspond to the slopes of the linear fits of the plots of $\ln \left([\mathrm{ENO}]_{0} /[\mathrm{ENO}]\right)$ versus time (Table 1$)$. The decrease of $\mathrm{k}_{\mathrm{app}}$ can most likely be attributed to the gradual acceleration of competitive reactions between hydroxyl radicals and the oxidation intermediates of ENO that were formed during the process (Flox et al., 2007 and Sirés et al., 2007a). Furthermore, even if the amount of ENO increased in solution, the number of OH produced remained constant. As a consequence, hydroxyl radicals were the limiting reagent of the degradation of ENO (Flox et al., 2006).

Table 1.

Apparent kinetic rate constants $\mathrm{k}_{\mathrm{app}}$ obtained during the EF treatment at various initial ENO concentrations, Fe(II) concentrations and applied current intensity. 


\begin{tabular}{|c|c|c|c|}
\hline $\begin{array}{c}\text { Initial ENO } \\
\text { concentration } \\
\left(\mathrm{mg} \mathrm{L}^{-1}\right)\end{array}$ & $\begin{array}{c}\mathrm{Fe}(\mathrm{II}) \text { concentration } \\
\left(\mathrm{mmol} \mathrm{L}^{-1}\right)\end{array}$ & $\begin{array}{l}\text { Applied current } \\
\text { intensity (mA) }\end{array}$ & $\begin{array}{l}\text { Apparent kinetic } \\
\text { rate constant } k_{\text {app }} \\
\qquad\left(\mathrm{min}^{-1}\right)\end{array}$ \\
\hline 50 & 0.2 & 200 & 0.082 \\
\hline 75 & 0.2 & 200 & 0.075 \\
\hline 100 & 0.2 & 200 & 0.075 \\
\hline 200 & 0.2 & 200 & 0.032 \\
\hline 50 & 0.1 & 200 & 0.055 \\
\hline 50 & 0.2 & 200 & 0.082 \\
\hline 50 & 0.5 & 200 & 0.049 \\
\hline 50 & 1 & 200 & 0.039 \\
\hline 50 & 0.2 & 50 & 0.045 \\
\hline 50 & 0.2 & 100 & 0.048 \\
\hline 50 & 0.2 & 200 & 0.082 \\
\hline 50 & 0.2 & 300 & 0.094 \\
\hline
\end{tabular}

\subsubsection{Effect of the $\mathrm{Fe}(\mathrm{II})$ concentration}

The effect of $\mathrm{Fe}$ (II) on the degradation of the target molecule was investigated in the presence of $50 \mathrm{mg} \mathrm{L}^{-1}$ of ENO and for an applied constant current intensity of $200 \mathrm{~mA}$. The ENO degradation yields increased with increasing $\mathrm{Fe}(\mathrm{II})$ concentration from 0.1 to $0.2 \mathrm{mmol} \mathrm{L}^{-1}$, while it decreased above $0.2 \mathrm{mmol} \mathrm{L}^{-1}$ (Fig. 3). On the one hand, the increase of the degradation efficiency observed between 0.1 and $0.2 \mathrm{mmol} \mathrm{L}^{-1}$ can be attributed to the higher production of hydroxyl radicals for increasing amount of Fe(II), according to the Fenton reaction (2) (Panizza and Cerisola, 2009). On the other hand, the negative effect of the Fe(II) amount beyond $0.2 \mathrm{mmol} \mathrm{L}^{-1}$ should be most likely attributed to a competitive reaction occurring between the hydroxyl radicals generated and the excess of ferrous ions according to the reaction (5) (Panizza and Cerisola, 2009 and Sun and Pignatello, 1993):

$\mathrm{Fe}^{2+}+\mathrm{OH} \rightarrow \mathrm{Fe}^{3+}+\mathrm{OH}^{-} \mathrm{Fe} 2++\mathrm{OH} \rightarrow \mathrm{Fe} 3++\mathrm{OH}^{-}$ 


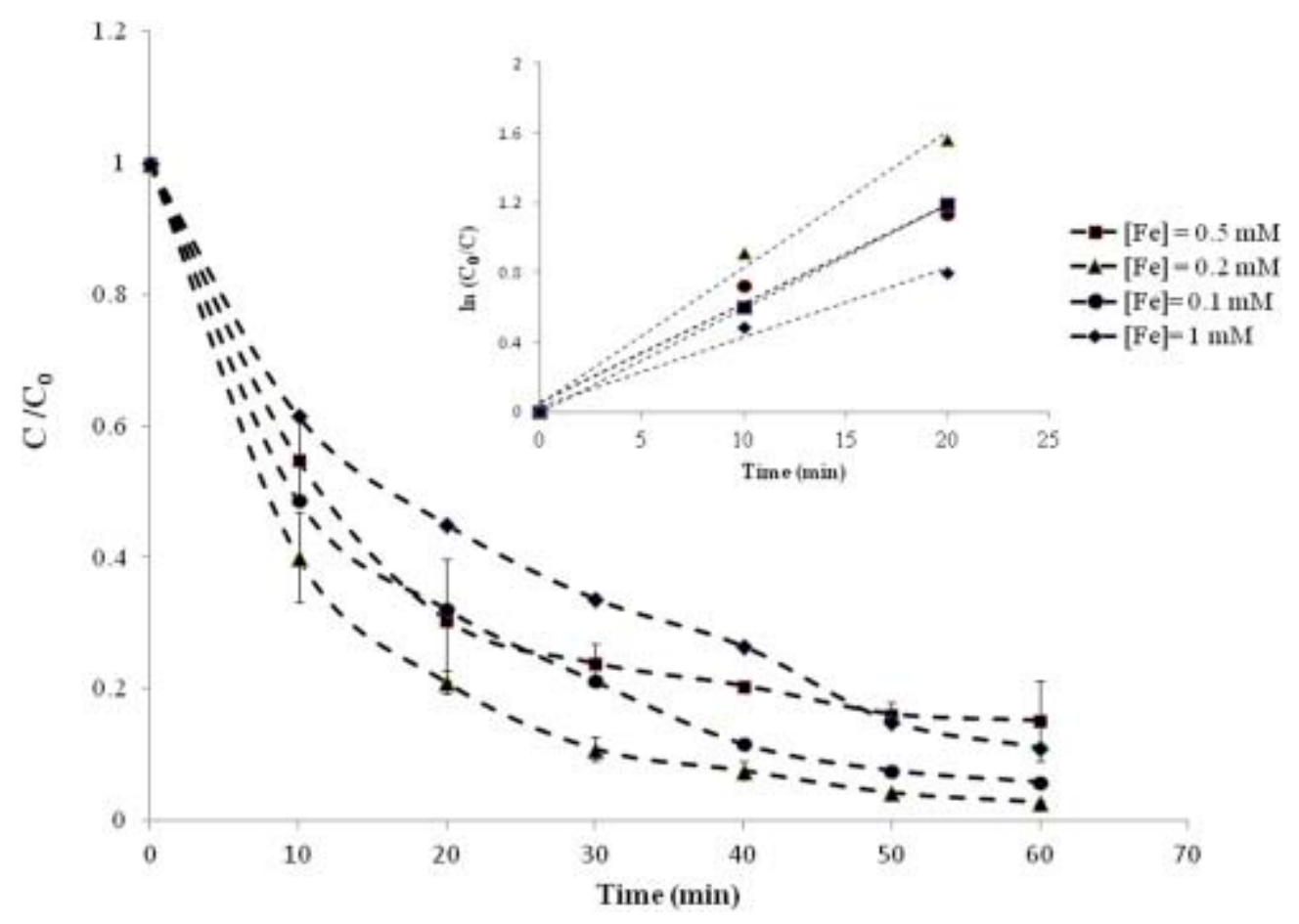

Fig. 3.

Effect of Fe (II) concentration on ENO degradation and kinetic analysis for the pseudo first-order reaction of ENO. Experimental conditions: $\mathrm{C}_{0}=50 \mathrm{mg} \mathrm{L}^{-1}, \mathrm{I}=200 \mathrm{~mA}$, $\mathrm{pH}=3,\left[\mathrm{Na}_{2} \mathrm{SO}_{4}\right]=50 \mathrm{mmol} \mathrm{L}^{-1}, \mathrm{~V}=250 \mathrm{~mL}$.

The inset of the panel of Fig. 3 shows that experimental kinetics are well described by a pseudo-first order reaction rate. The values of the apparent rate constant $\mathrm{k}_{\mathrm{app}}$ presented the same evolution than the degradation efficiency, they increased with increasing Fe(II) concentration until $0.2 \mathrm{mmol} \mathrm{L}^{-1}$ of catalyst and decreased beyond this $\mathrm{Fe}(\mathrm{II})$ amount (Table 1). As a consequence and in order to reach optimal results, $0.2 \mathrm{mmol} \mathrm{L}^{-1}$ of Fe(II) was employed as a catalyst concentration in the rest of the electrolyzes performed in this study.

\subsubsection{Effect of the applied current intensity}

The current intensity is a key parameter in the effectiveness of the EF process (Oturan et al., 2008 and Ozcan et al., 2009). To investigate its effect, experiments were carried out for $50 \mathrm{mg} \mathrm{L}^{-1}$ ENO and $0.2 \mathrm{mmol} \mathrm{L}^{-1}$ of $\mathrm{Fe}(\mathrm{II})$ and current intensities varying in the range 50 $300 \mathrm{~mA}$. The obtained results show that an increase in the current intensity improved the ENO degradation yields, from $74 \%$ after 30 min of electrolysis at $50 \mathrm{~mA}$ to $91 \%$ for $300 \mathrm{~mA}$ (Fig. 4). The improvement appeared more significant at the examination of $k_{\text {app }}$ of the pseudofirst order kinetic model showing an increase from $0.048 \mathrm{~min}^{-1}$ to $0.094 \mathrm{~min}^{-1}$ for current intensities increasing from 50 to $300 \mathrm{~mA}$ (inset of Fig. 4 and Table 1). The increase of the degradation yield associated with the increase of the current intensity can be explained by an increase of hydrogen peroxide production (see Supplementary material 2) and an increase of the regeneration rate of $\mathrm{Fe}(\mathrm{II})$ at the cathode, leading to a higher amount of hydroxyl radicals produced (Oturan et al., 2008 and Ozcan et al., 2009). 


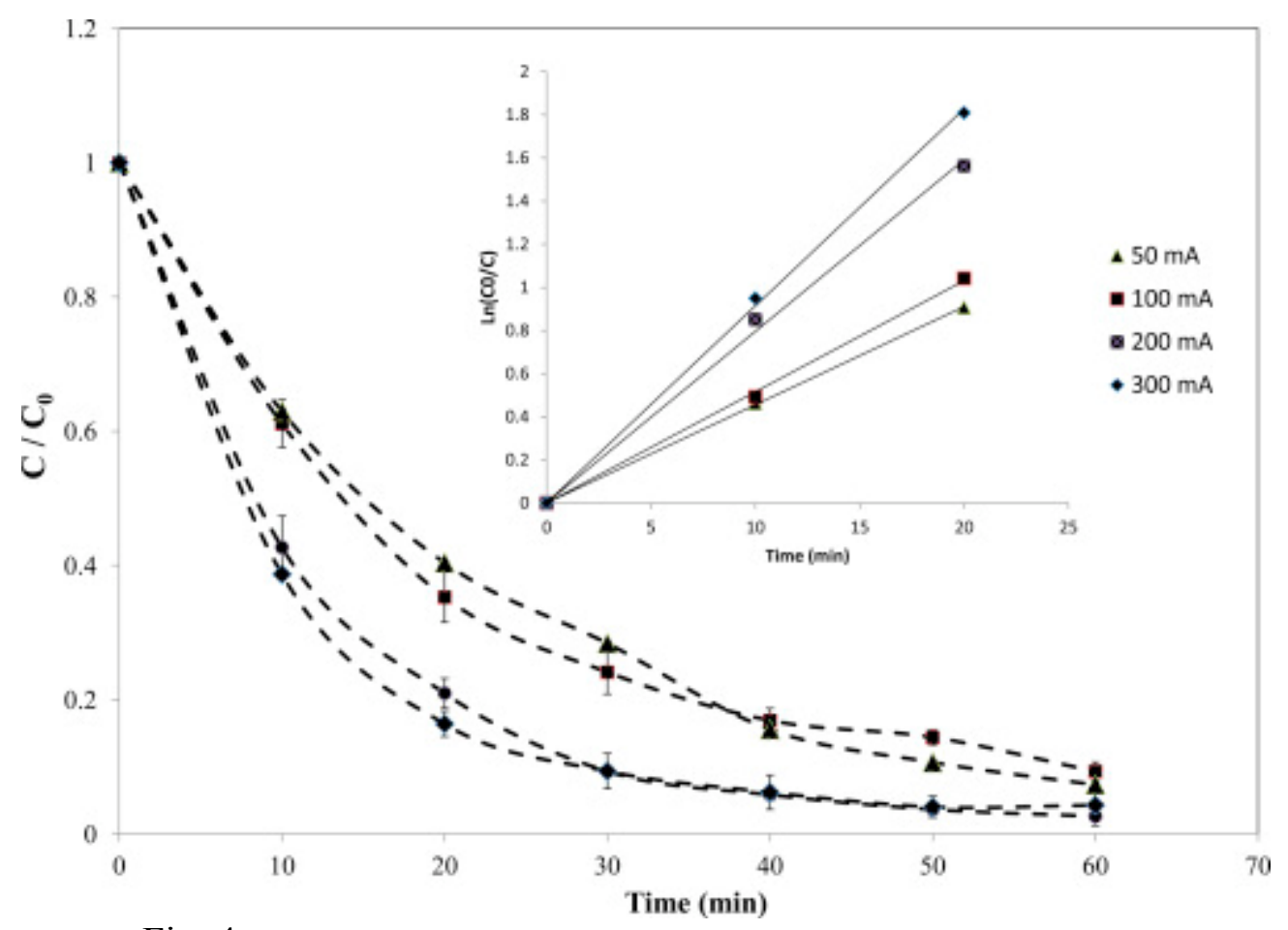

Fig. 4.

Effect of the applied current intensity on the ENO degradation and kinetic analysis for the pseudo first-order reaction of ENO. Experimental conditions: $\mathrm{C}_{0}=50 \mathrm{mg} \mathrm{L}^{-1}$, $[\mathrm{Fe}(\mathrm{II})]=0.2 \mathrm{mmol} . \mathrm{L}^{-1}, \mathrm{pH}=3,\left[\mathrm{Na}_{2} \mathrm{SO}_{4}\right]=50 \mathrm{mmol} \mathrm{L}{ }^{-1}, \mathrm{~V}=250 \mathrm{~mL}$.

Furthermore, the concentration of electrogenerated $\mathrm{H}_{2} \mathrm{O}_{2}$ during electrolysis can decrease when the current intensity increase, since oxygen reduction can lead to water instead of $\mathrm{H}_{2} \mathrm{O}_{2}$ at the cathode and owing to possible direct oxidation of $\mathrm{H}_{2} \mathrm{O}_{2}$ in a monocompartment electrochemical cell at the anode (Brillas et al., 2009). These assumptions can account for the very close results obtained at $200 \mathrm{~mA}$ and $300 \mathrm{~mA}$ (Fig. 4 and Table 1).

Results obtained at 50 and $100 \mathrm{~mA}$ were similar; no significant effect on enoxacin degradation was observed. The apparent kinetic constants (Table 1) were then similar $(0.045$ and $0.048 \mathrm{~min}^{-1}$ respectively).

\subsection{Electro-Fenton efficiency on the mineralization of enoxacin}

The above results have shown that the optimal conditions for the degradation of enoxacin by the electro-Fenton process were $[\mathrm{ENO}]_{0}=50 \mathrm{mg} \mathrm{L}^{-1} ; \mathrm{I}=300 \mathrm{~mA}$ and $[\mathrm{Fe}(\mathrm{II})]=0.2 \mathrm{mmol} \mathrm{L}^{-1}$. To complete the analysis of the impact of this process on enoxacin removal, mineralization and oxidation were also monitored and are shown in Fig. 5. TOC and COD followed similar trends to that of enoxacin degradation, since a significant decrease occurred within 30 min of electrolysis, reaching 26 and 49\% decrease respectively (Fig. 5). Refractory organic by-products were most likely responsible of the low mineralization yield (Sirés et al., 2007b). From 60 min of treatment, an almost total enoxacin abatement was 
observed (97\%), while mineralization and oxidation remained limited, 43 and 54\% after 120 min, respectively (Fig. 5). The slight decrease of mineralization observed between 120 and $180 \mathrm{~min}$ of treatment has been previously attributed to the accumulation of organic recalcitrant aromatic rings (Babic et al., 2013). Furthermore, the amount of OH produced may be insufficient to mineralize the molecule.

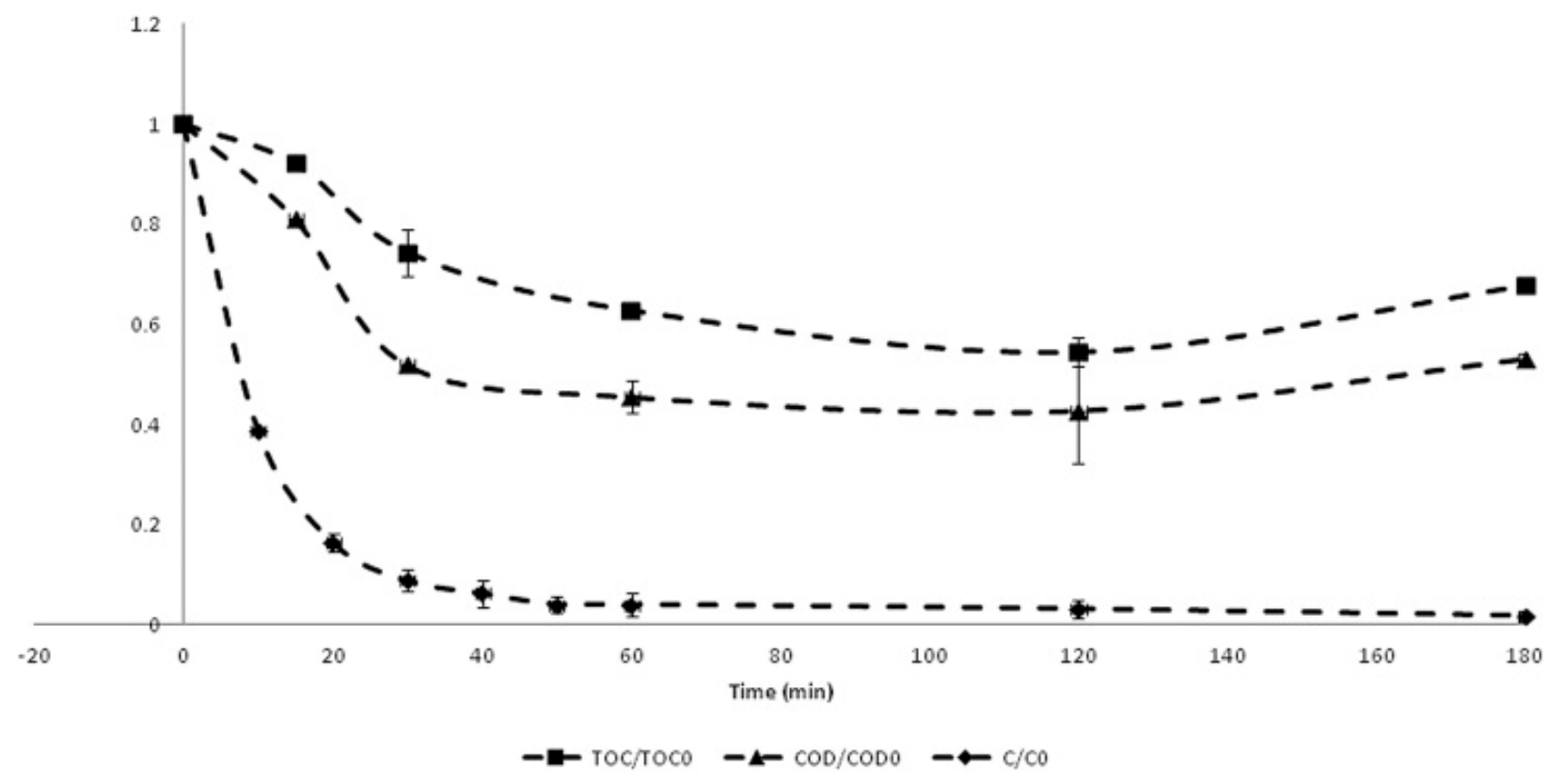

Fig. 5.

Time-course of ENO concentration, TOC and COD during ENO degradation by EF. Experimental conditions: $\mathrm{C}_{0}=50 \mathrm{mg} \mathrm{L}{ }^{-1}, \mathrm{I}=300 \mathrm{~mA},[\mathrm{Fe}(\mathrm{II})]=0.2 \mathrm{mM}, \mathrm{pH}=3$, $\left[\mathrm{Na}_{2} \mathrm{SO}_{4}\right]=50 \mathrm{mmol} \mathrm{L}^{-1}, \mathrm{~V}=250 \mathrm{~mL}$.

\subsection{Enoxacin biodegradability study}

The $\mathrm{BOD}_{5}$ on COD ratio is a recognized indicator of the biodegradability of a solution; this ratio must be higher or equal to 0.4 to consider that the solution is easily biodegradable (Salles et al., 2010). As expected, enoxacin was not biodegradable before electrolysis (Fig. 6).

Biodegradability increased after 60 min electrolysis at $300 \mathrm{~mA}$, with a $\mathrm{BOD}_{5}$ on COD ratio of 0.25 , showing that primary by-products were relatively resistant to micro-organisms.

However, a readily biodegradable solution, with a ratio of 0.51 was obtained after 180 min of electrolysis. It can be explained by the oxidation of the remaining recalcitrant by-products previously generated via the hydroxyl radicals (Mansour et al., 2012). However, for a longer electrolysis time, the obtained electrolyzed solution became less biodegradable since the $\mathrm{BOD}_{5}$ on COD ratio decreased from 0.51 to 0.30 after $360 \mathrm{~min}$, in agreement with the related literature (Mousset et al., 2014), and which may be related to the accumulation of recalcitrant quinolone rings for increasing electrolysis time (Babic et al., 2013). From this, the relevance of an EF pretreatment was confirmed and 180 min electrolysis of the ENO solution is required for an effective biological treatment. 


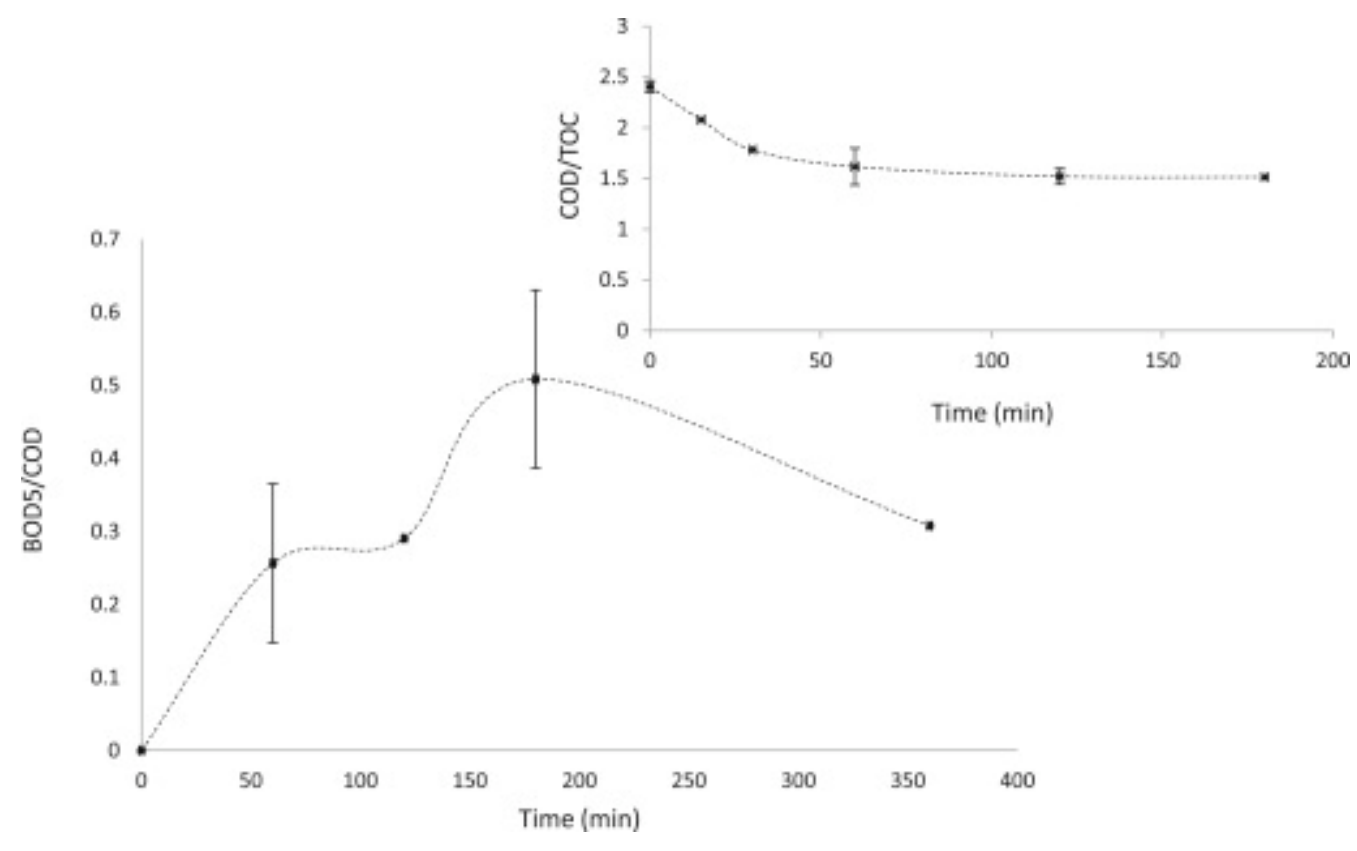

Fig. 6.

Evolution of the $\mathrm{BOD}_{5}$ on $\mathrm{COD}$ ratio and the $\mathrm{COD}$ on $\mathrm{TOC}$ ratio during electrolysis. Experimental conditions: $\mathrm{C}_{0}=50 \mathrm{mg} \mathrm{L}^{-1}, \mathrm{I}=300 \mathrm{~mA},[\mathrm{Fe}(\mathrm{II})]=0.2 \mathrm{mmol} \mathrm{L}^{-1}$, $\mathrm{pH}=3,\left[\mathrm{Na}_{2} \mathrm{SO}_{4}\right]=50 \mathrm{mmol} \mathrm{L}^{-1}, \mathrm{~V}=250 \mathrm{~mL}$.

The relevance of the coupling of an EF pretreatment and a biological process can be also estimated from the examination of the evolution of the COD/TOC ratio, displayed in the inset of Fig. 6. A favorable trend is a decrease of this ratio (Chebli et al., 2010), which was experimentally observed after EF pretreatment. In accordance with the improvement of the solution's biodegradability, the COD/TOC ratio decreased from 2.40 for an untreated solution to 1.62 for $60 \mathrm{~min}$ of electrolysis. The ratio COD/TOC then slightly decreased to 1.51 after 180 min of treatment.

\subsection{Evolution of the generated inorganic ions}

The enoxacin molecule contains an atom of fluorine and three atoms of nitrogen. The progressive generation of inorganic ions such as fluorides $\mathrm{F}^{-}$, nitrates $\mathrm{NO}_{3}{ }^{-}$and ammonium $\mathrm{NH}_{4}{ }^{+}$was therefore not surprising (Fig. 7 (a)). However, no nitrite $\mathrm{NO}_{2}{ }^{-}$anions were detected. The mineralization of enoxacin was therefore accompanied by the conversion of its heteroatoms into inorganic ions (El-Desoky et al., 2010). Ammonium concentration increased progressively until reaching a constant value of $0.12 \mathrm{mmol} \mathrm{L}^{-1}$ after $120 \mathrm{~min}$ of treatment. Nitrates remained constant throughout the electrolysis and did not exceed $25 \mu \mathrm{mol} \mathrm{L}{ }^{-1}$. 
(a)
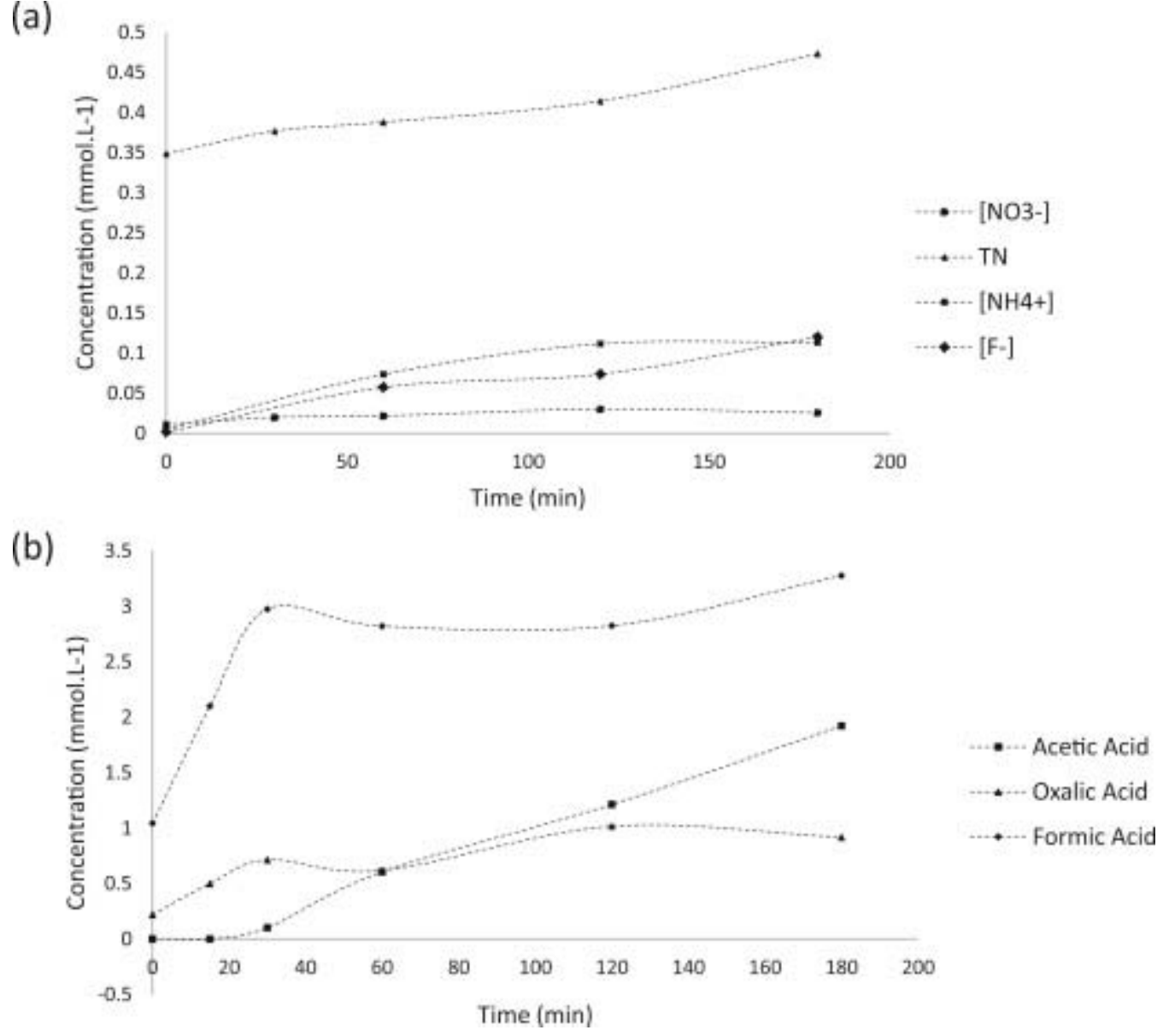

Fig. 7.

Time-course of the concentration of (a) inorganic species and (b) carboxylic acids during ENO degradation by EF. Experimental conditions: $\mathrm{C}_{0}=50 \mathrm{mg} \mathrm{L}^{-1}$; $\mathrm{I}=300 \mathrm{~mA},[\mathrm{Fe}(\mathrm{II})]=0.2 \mathrm{mmol} \mathrm{L}{ }^{-1} ;\left[\mathrm{Na}_{2} \mathrm{SO}_{4}\right]=50 \mathrm{mmol} \mathrm{L}^{-1} ; \mathrm{t}=60 \mathrm{~min}, \mathrm{pH}=3$, $\mathrm{V}=250 \mathrm{~mL}$.

$24 \%$ of the nitrogen atoms of the target molecule were transformed into ammonium, while only $5 \%$ were transformed into nitrates after $120 \mathrm{~min}$. The percentage of undetected nitrogen may be related to the presence of nitrogen in the degradation products, such as the stable Nderivatives found by LC-MS/MS (Garcia-Segura et al., 2012). The fluorides amount increased continuously until the end of electrolysis, reaching a value of $0.12 \mathrm{mmol} \mathrm{L}^{-1}$, namely $77 \%$ of the fluorine likely to be found after a total conversion $\left(0.16 \mathrm{mmol} \mathrm{L}^{-1}\right)$. The fluorine atoms unconverted into inorganic ions are likely to be included in the structure of some degradation by-products (Babic et al., 2013 and Garcia-Segura et al., 2012).

\subsection{Study of the generated carboxylic acids}

The degradation of aromatics and heteroatoms by hydroxyl radicals involves the generation of short-linear aliphatic carboxylic acids, produced from the cleavage of their aromatic moieties and lateral groups (Garcia-Segura et al., 2012). Based on this information, it can be noticed that the degradation of $50 \mathrm{mg} \mathrm{L}^{-1}$ of enoxacin by EF at $300 \mathrm{~mA}$ was also accompanied by the 
generation of several carboxylic acids. Three of them were identified by Ion Chromatography, presenting well defined peaks: formic (6.22 $\mathrm{min})$, acetic $(5.44 \mathrm{~min})$ and oxalic $(21.08 \mathrm{~min})$ acids. A progressive increase of the acids concentration was observed during the course of electrolysis (Fig. 7 (b)), with the higher concentration (more than $3 \mathrm{mg} \mathrm{L}^{-1}$ ) observed for formic acid (C-1 acid) compared to acetic and oxalic acids (C-2 acid). It can be interpreted by the transformation of the $\mathrm{C}-2$ acids into a $\mathrm{C}-1$ acid, due to the hydroxyl radicals' attack (Garcia-Segura et al., 2012). Note that oxalic and formic acids are ultimate carboxylic acids because they can be directly converted into $\mathrm{CO}_{2}$ (Garcia-Segura and Brillas, 2011 and Oturan et al., 2008).

On the other hand, it has been reported that under EF conditions, carboxylic acids form complexes with $\mathrm{Fe}(\mathrm{III})$ present in the solution according to the Fenton reaction (reaction 3) (Brillas et al., 2009). This can explain the behavior of formic and oxalic acids (Fig. 7 (b)), which were accumulated within the first $30 \mathrm{~min}$ of electrolysis, reaching a plateau after this time. To account for this trend, it can be assumed that they probably reacted with $\mathrm{Fe}(\mathrm{III})$ and then their complexes rapidly reacted with hydroxyl radicals (Garcia-Segura and Brillas, 2011). In contrast, acetic acid was more recalcitrant and increased progressively, reaching $1.94 \mathrm{mg} \mathrm{L}^{-1}$ after $180 \mathrm{~min}$ of treatment.

The carboxylic acids accumulated at the end of the electrolysis were involved in the residual TOC displayed in Fig. 5 (Garcia-Segura et al., 2012).

\subsection{Elucidation of by-products and mechanism of degradation}

Based on the results of the UPLC-MS/MS analysis, four by-products were detected after 30 and 60 min of treatment (Table 2), which allowed to suggest a general pathway for ENO degradation by EF (Fig. 8).

Table 2.

Intermediates products generated during the EF degradation of enoxacin.

\begin{tabular}{|c|c|c|c|}
\hline Products & ReteI & MH & Ion fragments $\left(\mathrm{g} \mathrm{mol}^{-1}\right)$ \\
\hline & & & 303 \\
\hline Fnoxacin & 123 & 321 & 257 \\
\hline Liloxactil & & & 234 \\
\hline & & & 206 \\
\hline & & & 333 \\
\hline FNO I & 168 & 351 & 305 \\
\hline & & & 259 \\
\hline & & & 232 \\
\hline & & & 305 \\
\hline ENO II & 1.8 & 323 & 259 \\
\hline & & & 232 \\
\hline & & & 262 \\
\hline ENO III & 1.8 & 280 & 234 \\
\hline & & & 206 \\
\hline
\end{tabular}




\section{Products Retention time (min) $\mathrm{MH}^{+}\left(\mathrm{g} \mathrm{mol}^{-1}\right)$ Ion fragments $\left(\mathrm{g} \mathrm{mol}^{-1}\right)$}

ENO IV 2.02
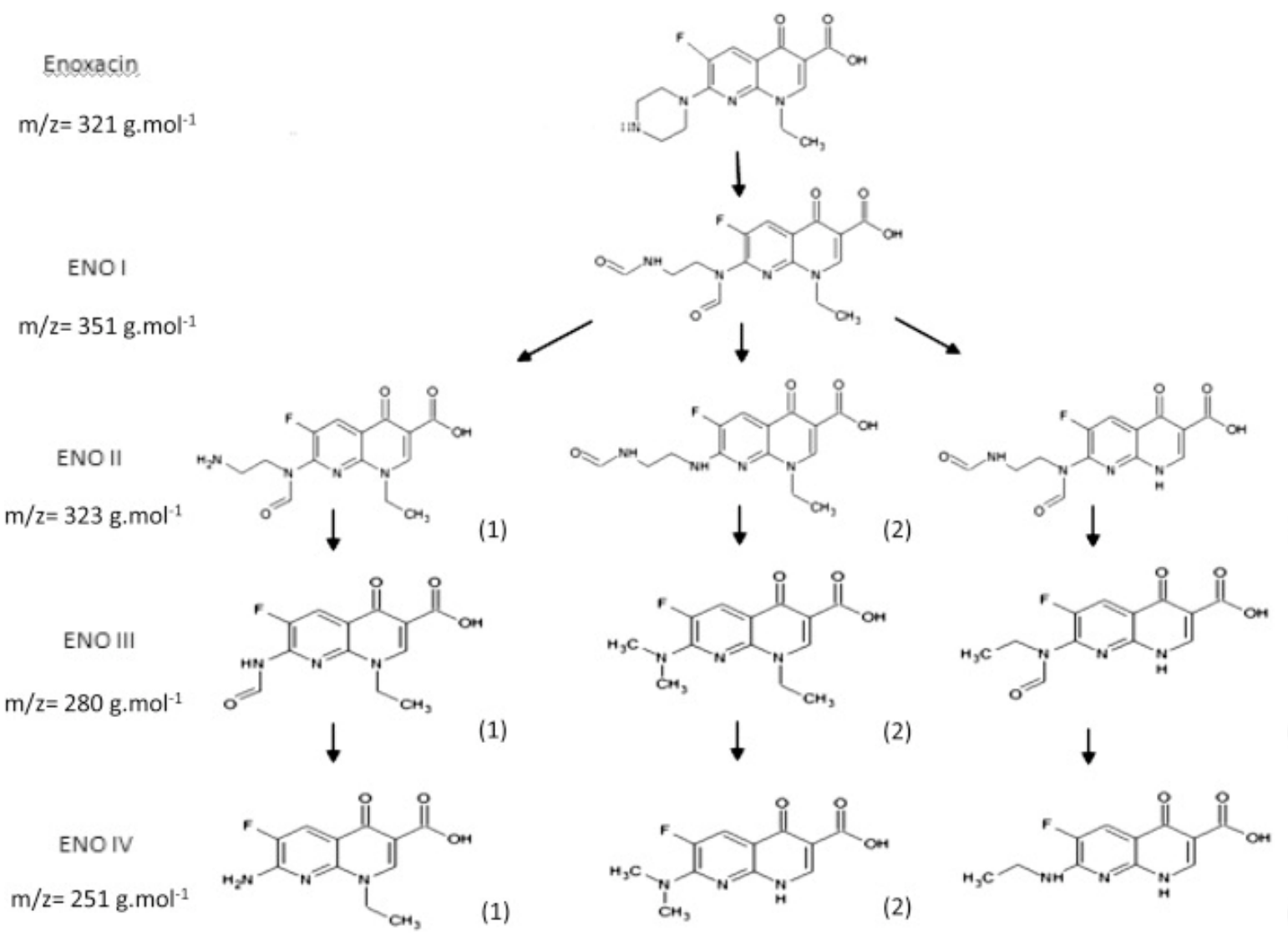

Fig. 8.

Proposed structures for by-products of enoxacin EF degradation.

There is no literature dealing with the degradation pathway of enoxacin. The proposed mechanism of ENO degradation is based on the mass spectra of intermediates, on the molecular weight of ion fragments derived from each degradation product and on previous studies done on other FQs (Babic et al., 2013, Dolar et al., 2013 and Sturini et al., 2012).

For each molecular mass found, various structures were suggested. Indeed, inorganic species time courses showed only a partial generation of fluorides, nitrates and ammonium, and hence the presence of by-products with or without heteroatoms is possible. Moreover, after $30 \mathrm{~min}$ of treatment, $87 \%$ of ENO was removed, so that the hydroxyl radicals generated can attack the by-products, accounting for the presence of a significant amount of short carboxylic acids after 30 min of degradation (Fig. 7 (b)). 
According to the literature, ENO may be first attacked on its piperazine ring, seeing that it is the most oxidable part of the molecule (Babic et al., 2013). The structures of ENO I came principally from the opening of the piperazine ring and its transformation into two groups of amides (Babic et al., 2013). It was made up of oxidative rearrangements on the N-ethyl piperazine chain. The N-ethyl substituent of the benzo ring may also be oxidized on aldehyde group (not shown).

The second step consisted in the elimination of an ethyl group from the N-ethyl substituent or the elimination of a carbon monoxyde (CO) molecule from one of the amide groups to obtain ENO II structures.

ENO III and ENO IV structures resulted from the successive elimination of an ethyl, a carbon monoxide and/or an ammonia molecule $\left(\mathrm{NH}_{3}\right)$, in order to obtain diverse possible byproducts, including a primary, a secondary or a tertiary amine in their structures (Babic et al., 2013 and Sturini et al., 2012).

In accordance with older studies, all the intermediates suggested showed the persistence of the quinolone ring in their structures, which explain the high residual TOC and COD in the treated solution.

Short carboxylic acids generated during electrolysis may derive from ENO IV by-products (Babic et al., 2013 and Vasconcelos et al., 2009).

The nomenclature of enoxacin intermediates suggested in this study is given in supplementary material (Supplementary material 3).

\section{Conclusion}

The present paper proves the effectiveness of the electro-Fenton treatment for the remediation of the fluoroquinolone enoxacin present in wastewaters and in surface water. Around $98 \%$ degradation yield was obtained after $60 \mathrm{~min}$ of electrolysis in the optimal experimental conditions, namely $50 \mathrm{mg} \mathrm{L}^{-1}$ initial enoxacin amount, $300 \mathrm{~mA}$ and $0.2 \mathrm{mmol} \mathrm{L}^{-1} \mathrm{Fe}(\mathrm{II})$. Furthermore, biodegradability was enhanced after $180 \mathrm{~min}$ of treatment with a maximum $\mathrm{BOD}_{5}$ on COD ratio of 0.51 ; while TOC removal yield did not exceed $32 \%$ after this electrolysis time. It can be explained by the generation of recalcitrant by-products during electrolysis and the persistence of the quinolone ring. This behavior was confirmed by the primary products found during UPLC-MS/MS analyses.

After 180 min electrolysis of $50 \mathrm{mg} \mathrm{L}^{-1} \mathrm{ENO}, 77 \%$ of the fluorine contained in the target compound was converted into fluorides. Moreover, the nitrogen content of ENO was partially converted to nitrate $(5 \%)$ and ammonium $(24 \%)$ ions. Oxalic, acetic and formic acids were also formed, which can be easily mineralized leading to $\mathrm{CO}_{2}$ and $\mathrm{H}_{2} \mathrm{O}$.

From the above results, EF is certainly suitable for the removal of ENO in wastewaters. It also presents a relevant solution and an effective pretreatment for the improvement of biodegradability. Further studies could be considered as a perspective in order to optimize the ideal electrolysis time for good biodegradability.

\section{Appendix A. Supplementary data}


Attached

\section{References}

An, T., Yang, H., Li, G., Song, W., Cooper, W.J., Nie, X., 2010. Kinetics and mechanism of advanced oxidation processes (AOPs) in degradation of ciprofloxacin in water.

Appl. Catal. B-Environ. 94, 288e294.

Assassi, M., Fourcade, F., Geneste, F., Floner, D., Maachi, R., Amrane, A., 2011. Combined electrochemical and biological treatment for pesticide degradation -

Application to phosmet. Int. J. Environ. Res. 5, 41e46.

Babic, S., Perisa, M., Skoric, I., 2013. Photolytic degradation of norfloxacin, enrofloxacin and ciprofloxacin in various aqueous media. Chemosphere 91, $1635 \mathrm{e} 1642$.

Bound, J.P., Voulvoulis, N., 2005. Household disposal of pharmaceuticals as a pathway for aquatic contamination in the United Kingdom. Env. Health. Perspect. $113,1705 \mathrm{e} 1711$.

Brillas, E., Sires, I., Oturan, M.A., 2009. Electro-Fenton process and related electrochemical technologies based on Fenton's reaction chemistry. Chem. Rev. 109, $6570 \mathrm{e} 6631$.

Chebli, D., Fourcade, F., Brosillon, S., Nacef, S., Amrane, A., 2010. Supported photocatalysis as a pre-treatment prior to biological degradation for the removal of some dyes from aqueous solutions ; acid red 183, Biebrich scarlet, methyl red sodium salt, orange II. J. Chem. Technol. Biotechnol. 85, 555e563.

Daughton, C., Ternes, T., 1999. Pharmaceutical and personal care products in the environment: agents of subtle change ? Env. Health. Perspect. 107, 907e938.

Diagne, M., Oturan, N., Oturan, M.A., 2007. Removal of methyl parathion from water by electrochemically generated Fenton's reagent. Chemosphere 66, 841e848. Dolar, D., Kosutic, K., Perisa, M., Babic, S., 2013. Photolysis of enrofloxacin and removal of its photodegradation products from water by reverse osmosis and nanofiltration membranes. Sep. Purif. Technol. 115, 1 e8.

El-Desoky, H.S., Ghoneim, M.M., El-Sheikh, R., Zidan, N.M., 2010. Oxidation of Levafix CA reactive azo-dyes in industrial wastewater of textile dyeing by electro-generated Fenton's reagent. J. Hazard. Mater. 175, 858e865.

Ellis, J.B., 2006. Pharmaceutical and personal care products (PPCPs) in urban receiving waters. Environ. Pollut. 144, 184e189.

Feng, L., Van Hullebusch, E.D., Rodrigo, M.A., Esposito, G., Oturan, M.A., 2013.

Removal of residual anti-inflammatory and analgesic pharmaceuticals from aqueous systems by electrochemical advanced oxidation processes. A review. Chem. Eng. J. 228, 944e964.

Ferrag-Siagh, F., Fourcade, F., Soutrel, I., Aït-Amar, H., Djelal, H., Amrane, A., 2013. Tetracycline degradation and mineralization by the coupling of an electroFenton pretreatment and a biological process. J. Chem. Technol. Biotechnol. $88,1380 \mathrm{e} 1386$.

Flox, C., Ammar, S., Arias, C., Brillas, E., Vargas-Zavala, A., Abdelhedi, R., 2006.

Electro-Fenton and photoelectron-Fenton degradation of indigo carmine in acidic aqueous medium. Appl. Catal. B-Environ. 67, 93e104.

Flox, C., Garrido, J.A., Rodriguez, R.M., Cabot, P.I., Centellas, F., Arias, C., Brillas, E., 2007. Mineralization of herbicide mecoprop by photoelectro-Fenton with UVA and solar light. Catal. Today 129, 29e36.

Garcia-Segura, S., Garrido, J.A., Rodriguez, R.M., Cabot, P.I., Centellas, F., Arias, C., 
Brillas, E., 2012. Mineralization of flumequine in acidic medium by electro-

Fenton and photoelectro-Fenton processes. Water Res. 46, 2067e2076.

Garcia-Segura, S., Brillas, E., 2011. Mineralization of the recalcitrant oxalic and oxamic acids by electrochemical advanced oxidation processes using a borondoped diamond anode. Water Res. 45, 2975e2984.

Giger, W., Alder, A.C., Golet, E.M., Kohler, H.P.E., McArdell, C.S., Molnar, E., Siegrist, H., Suter, M.J.F., 2003. Occurrence and fate of antibiotics as trace contaminants in wastewaters, sewage sludges, and surface waters. Chim. Int. J.

Chem. 57, 485e491.

Golet, E.M., Alder, A.C., Giger, W., 2002. Environmental exposure and risk assessment of fluoroquinolone antibacterial agents in wastewater and river water of the Glatt Valley Watershed, Switzerland. Environ. Sci. Technol. 36, $3645 \mathrm{e} 3651$.

Guivarch, E., Oturan, N., Oturan, M.A., 2003. Removal of organophosphorus pesticides from water by electrogenerated Fenton's reagent. Environ. Chem. Lett. 1, $165 \mathrm{e} 168$.

Guinea, E., Garrido, J.A., Rodriguez, R.M., Cabot, P.L., Arias, C., Centellas, F., Brillas, E., 2010. Degradation of the fluoroquinolone enrofloxacin by electrochemical advanced oxidation processes based on hydrogen peroxide electrogeneration. Electrochim. Acta 55, 2101e2115.

Hammami, S., Bellakhal, N., Oturan, M.A., Dachraoui, M., 2008. Degradation of acid orang 7 by electrochemically generated $\mathrm{OH}$ radicals in acidic aqueous medium using a boron-doped diamond or platinum anode: a mechanistic study. Chemosphere $73,678 \mathrm{e} 684$.

Hendricks, R., Pool, E.J., 2012. The effectiveness of sewage treatment processes to remove faecal pathogens and antibiotic residues. J. Environ. Sci. Health 47, $289 \mathrm{e} 297$.

Hernando, M.D., Mezcua, M., Fernandez-Alba, A.R., Bercelo, D., 2006. Environmental risk assessment of pharmaceutical residues in wastewater effluents, surface waters and sediments. Talanta 69, 334e 342 .

Ikehata, K., Naghashkar, N.J., El-Din, M.G., 2006. Degradation of aqueous pharmaceuticals by ozonation and advanced oxidation processes : a review. Ozone-Sci.

Eng. 25, 353e414.

Klavarioti, M., Mantzavinos, D., Kassinos, D., 2009. Review article removal of residual pharmaceuticals from aqueous systems by advanced oxidation processes.

Environ. Int. 35, 402e417.

Levy, S., 1998. The challenge of antibiotic resistance. Sci. Am. 278, 46e53.

Lin, A.C., Yu, T.H., Lin, C.F., 2008. Pharmaceutical contamination in residential, industrial, and agricultural waste streams: risk to aqueous environments in

Taiwan. Chemosphere 74, 131e141.

Lindberg, R.H., Olofsson, U., Rendahl, P., Johansson, M.I., Tysklind, M., Andersson, B.A.V., 2006. Behavior of fluoroquinolones and trimethoprim during mechanical, chemical and active sludge treatment of sewage water and digestion of sludge. Environ. Sci. Technol. 40, 1042e1048.

Mansour, D., Fourcade, F., Bellakhal, N., Dachraoui, M., Hauchard, D., Amrane, A., 2012. Biodegradability improvement of sulfamethazine solutions by means of an electro-Fenton process. Water Air Soil Pollut. 223, $2023 \mathrm{e} 2034$.

Mousset, E., Oturan, N., Van Hullebusch, E.D., Guibaud, G., Esposito, G., Oturan, M.A., 2014. Treatment of synthetic soil washing solutions containing phenanthrene and cyclodextrin by electro-oxidation. Influence of anode materials on toxicity 
removal and biodegradability enhancement. Appl. Catal. B Environ. 160e161, $666 \mathrm{e} 675$.

Nasuhoglu, D., Rodayan, A., Berk, D., Yargeay, V., 2012. Removal of the antibiotic levofloxacin (LEVO) in water by ozonation and $\mathrm{TiO} 2$ photocatalysis. Chem. Eng. J. $189 \mathrm{e} 190,41 \mathrm{e} 48$.

Oturan, M.A., Pimentel, M., Oturan, N., Sires, I., 2008. Reaction sequence for the mineralization of the short-chain carboxylic acids usually formed upon cleavage of aromatics during electrochemical Fenton treatment. Electrochem. Acta 54, $173 \mathrm{e} 182$.

Ozcan, A., Oturan, M.A., Oturan, N., Sahin, Y., 2009. Removal of acid orange 7 from water by electrochemically generated Fenton's reagent. J. Hazard. Mater. 163, $1213 \mathrm{e} 1220$.

Panizza, M., Cerisola, G., 2009. Electro-Fenton degradation of synthetic dyes. Water Res. 43, 339e344.

Patel, S.S., Spencer, C.M., 1996. Enoxacin: a reappraisal of its clinical efficacy in the treatment of genitourinary tract infections. Drugs 51, 137e160.

Pera-Titus, M., Garcia-Molina, V., Banos, M.A., Gim enez, J., Espulgas, S., 2004.

Degradation of chlorophenols by means of advanced oxidation processes: a

general review. Appl. Catal. B. Environ. 47, 219e256.

Rodier, J., Bazin, C., Broutin, J.P., 1996. L'analyse de l'eau : eaux naturelles, eaux $r$ esiduaires, eau de mer, eighth ed. Dunod, Paris, France.

Rodrigues-Silva, C., Maniero, M.G., Rath, S., Guimaraes, J.R., 2013. Degradation of flumequine by photocatalysis and evaluation of antimicrobial activity. Chem.

Eng. J. 224, 46e52.

Salles, N.A., Fourcade, F., Geneste, F., Floner, D., Amrane, A., 2010. Relevance of an electrochemical process prior to a biological treatment for the removal of an organo-phosphorous pesticide, phosmet. J. Hazard. Mater 181, 617e623.

Sir es, I., Arias, C., Cabot, P.I., Centellas, F., Garrido, J.A., Rodriguez, R.M., Brillas, E., 2007a. Degradation of clofibric acid in acidic aqueous medium by electro-

Fenton and photoelectro-Fenton. Chemosphere 66, 1660e1669.

Sir es, I., Brillas, E., Oturan, M.A., Rodrigo, M.A., Panizza, M., 2014. Electrochemical advanced oxidation processes: today and tomorrow. A review. Environ. Sci.

Pollut. Res. 21, 8336e8367.

Sir es, I., Garrido, J.A., Rodriguez, R.M., Brillas, E., Oturan, N., Oturan, M.A., $2007 b$. Catalytic behavior of the $\mathrm{Fe} 3 \mathrm{p} / \mathrm{Fe} 2 \mathrm{p}$ system in the electro-Fenton degradation of the antimicrobial chlorophene. Appl. Catal. B-Environ 72, 382e394.

Sturini, M., Speltini, A., Maraschi, F., Profumo, A., Pretali, L., Irastorza, E.A., Fasani, E., Albini, A., 2012. Photolytic and photocatalytic degradation of fluoroquinolones in untreated river water under natural sunlight. Appl. Catal. B-Environ 119, $32 \mathrm{e} 39$.

Sui, Q., Huang, J., Deng, S.B., Chen, W.W., Yu, G., 2011. Seasonal variation in the occurrence and removal of pharmaceuticals and personal care products in different biological wastewater treatment processes. Environ. Sci. Technol. 45, $3341 \mathrm{e} 3348$.

Sun, Y., Pignatello, J.J., 1993. Photochemical reactions involved in the total mineralization of 2,4-D by iron( $3 \mathrm{p}) /$ hydrogen peroxide/UV. Environ. Sci. Technol. 27, $304 \mathrm{e} 310$.

Van Doorslaer, X., Dewulf, J., Van Langenhove, H.D., Demeestere, K., 2014.

Fluoroquinolone

antibiotics : an emerging class of environmental micropolluants. 
Sci. Total Environ. 500e501, 250e269.

Van Doorslaer, X., Haylamicheal, I.D., Dewulf, J., Langenhove, H.V., Janssen, C.R., Demeestere, K., 2015. Heterogeneous photocatalysis of moxifloxacin in water : chemical transformation and ecotoxicity. Chemosphere 119, 575e580.

Vasconcelos, T.G., Henriques, D.M., Konig, A., Martins, A.F., Kummerer, K., 2009. Photo-degradation of the antimicrobial ciprofloxacin at high $\mathrm{pH}$ : identification and biodegradability assessment of the primary by-products. Chemosphere 76, $487 \mathrm{e} 493$.

Watkinson, A.J., Murby, E.J., Costanzo, S.D., 2007. Removal of antibiotics in conventional and advanced wastewater treatment: implications for environmental

discharge and wastewater recycling. Water Res. 41, 4164e4176.

Watkinson, A.J., Murby, E.J., Kolpin, D.W., Costanzo, S.D., 2009. The occurrence of antibiotics in an urban watershed: from wastewater to drinking water. Sci. Total Environ. 407, 2711e2723.

Xiao, R., He, Z., Diaz-Rivera, D., Pee, G.Y., Weavers, L.K., 2014. Sonochemical degradation of ciprofloxacin and ibuprofen in the presence of matrix organic compounds. Ultrason. Sonochem. 21, 428e435.

Xie, Y.B., Li, X.Z., 2006. Interactive oxidation of photoelectrocatalysis and electroFenton for azo dye degradation using TiO2-Ti mesh and reticulated vitreous carbon electrodes. Mater. Chem. Phys. 95, 39e50.

Yahya, M.S., Oturan, N., El Kacemi, K., El Karbane, M., Aravindakumar, C.T., Oturan, M.A., 2014. Oxidative degradation study on antimicrobial agent ciprofloxacin by electro-Fenton process : kinetics and oxidation products. Chemosphere $117,447 \mathrm{e} 454$.

Yahiat, S., Fourcade, F., Brosillon, S., Amrane, A., 2011. Removal of antibiotics integrated process coupling photocatalysis and biological treatment-case of tetracycline and tylosin. Int. Biodeterior. Biodegrad. 65, 997e1003.

Yam, A.A., Dioufndiaye, M., Badiane, M., Sawadogo, G., 1995. D etermination de la dose optimale de fluor dans l'eau de boisson au S enegal, TSM. Technol. Sci.

$\mathrm{M}$ ethodes 6, 488e490.

Yoon, Y., Ryu, J., Choi, B.G., Snyder, S.A., 2010. Occurrence of endocrine disrupting compounds, pharmaceuticals, and personal care products in the Han river (Seoul, South Korea). Sci. Total Environ. 408, 636e643.

Zhang, Z.Q., Li, Y.F., He, X.M., Zhang, Q., 1996. Electroanalytical characteristics of enoxacin and their analytical application. Talanta 46, 635e641.

Zhou, G.R., Fan, H.Z., Pan, J.H., 1995. Polarographic and voltammetric behaviour of enoxacin. Analyst 120, 2237e2239. 